\title{
Prefigurative Partaking: Employees' Environmental Activism in an Energy Utility
}

\author{
Annika Skoglund \\ Uppsala University Sweden and University of Exeter Business School, UK \\ Steffen Böhm \\ University of Exeter Business School, UK
}

Cite as:

Skoglund, A., \& Böhm, S. (2019). Prefigurative Partaking: Employees’ Environmental Activism in an Energy Utility. Organization Studies.

https://doi.org/10.1177/0170840619847716

\begin{abstract}
The separation between an 'inside' and 'outside' of organisational politics has become untenable in a rapidly changing political landscape, where people engage in environmental activism in many different domains. To understand contemporary environmental activism, we situate ourselves empirically within an energy utility, Ordalia [pseudonym], a large corporation active across Europe and heavily criticised by external activists for its carbon emitting operations. By merging Rancière's method of equality and notion of 'partaking' with literature on prefiguration in social movements, we analyse everyday green actions pursued by Ordalia's employees, which we conceptualise as 'prefigurative partaking'. By focusing on six characterising themes of prefigurative partaking - aspirational, individual, professional, critical, loyal and communal - we have found that employee activism is incremental, horizontal and boundaryless. We discuss these findings in relation to recent calls for more fruitful exchanges between social movement theory and organisation studies, arguing that Rancière's conceptualisation of politics can help us study actions that span civil society and business. This complements and expands our understanding of environmental activism as a dispersed set of actions that can take place anywhere, and hence at work.
\end{abstract}

Keywords: climate change, environmental activism, employees, prefiguration, Jacques Rancière

\section{Introduction}

The $4^{\text {th }}$ floor is definitely crowded with wind people. It should just be brimming, look at this house! Renewable people! There's no pride today in what we're doing! (Natalie, 2014)

Natalie, an employee at Ordalia [pseudonym], a multinational utility company, wonders vividly why her employer is not more active and proud concerning their wind power operations. After all, Ordalia has been heavily criticised by external environmental activists for their polluting operations, and would perhaps do better if renewable energy activities were given higher priority. The risk, her wind power colleagues add on multiple occasions, is that the company could be accused of greenwashing. Despite this obvious dilemma, some employees remain 
adamant they desire major changes in the environmental affairs of their employer. Yet, in their minds it is not enough to develop, plan and construct renewable energy projects, such as large scale wind power parks. They desire immediate changes in the here and now. So, to improve their workplace's environmental record, they engage in mundane everyday actions in the office, such as walking up the stairs and recycling colleagues' lunch waste.

How can we understand these small, everyday environmental actions? In this article we argue that there is a need to comprehend them as political moments. Complementing existing organizational research on 'prefigurative politics' (Boggs, 1977; Leach, 2013), and based on Jacques Rancière's (2016) method of equality, we conceptualize 'prefigurative partaking' to analyse everyday environmental activism within a large corporation.

We know from the very inception of the field of organisation studies that within organisations literally everybody can take part in politics (Bacharach \& Lawler, 1980). This ranges from overt or covert infra-politics (Scott, 2005) and misbehaviour (Ackroyd \& Thompson, 1999) to microemancipation (Alvesson \& Willmott, 1992), including a recent turn to performativity and 'alternative' forms of organisation (Parker \& Parker, 2017). Organisational politics have nevertheless mostly been defined in relation to multifaceted deployments of 'resistance' (Courpasson et al., 2012; Karfakis \& Kokkinidis, 2011), commonly analysed as formations of opposition and co-optation that summarise ambiguous control mechanisms with roots internally to organisational hierarchies (Ekman, 2014; Mumby et al., 2017).

This 'inside' perspective of organisational politics usually does not feature environmental issues, to which the field has had little exposure. While organisational scholars' interest in environmental politics is growing (Goworek et al., 2018; Wittneben et al., 2012; Wright et al., 2011), most of these studies treat environmental activism as an external force that impacts, or enters, corporations and institutions from an outside (e.g. Pacheco et al., 2014). This location of activism in an 'outside' that can affect 'inside' decision-making (Wright et al., 2012) is mostly the realm of civil society, the space where contentious politics (Tarrow, 2011) is enacted by activist campaign groups, NGOs and social movements.

Due to a renewed interest in social movements in organisation studies (e.g. Briscoe \& Gupta, 2016), there is an increased recognition of the blurred boundaries between civil society and corporations (e.g. Clegg et al., 2018; de Bakker et al., 2013; Yaziji \& Doh, 2013). Authors have studied how people's contentious politics enters the workplace, for example as 'labour activism' (Marens, 2013) or sexual identity activism (Creed \& Scully, 2000). It is thus important to recognise the potential of 'insider activism' as something performed by 'activists who are a company's employees' (Briscoe \& Gupta, 2016, p.673; see also Wickert \& De Bakker, 2018; Girschik, 2018). However, despite this ongoing blurring of the 'inside' and 'outside' perspectives of organisational politics (Davis et al., 2005; Soule, 2012; Weber \& King, 2014), studies of environmental activism within organisations are relatively scarce. While it has been argued that those corporations that foster internal green politics do so to create a diversion, protecting the (polluting) status quo (Nyberg et al., 2013), the question of precisely why employees' activism can be conceptualised as a form of politics that leads to transformations remains unexplored in the field. In this article we discuss another, transformative approach to politics, one that takes account of contemporary turbulent political landscapes and new trends in activism, understanding politics as something much more diffuse and dispersed than most organisational scholars acknowledge. 
Sparked by our experience from within Ordalia's wind power units in the UK and Sweden, we explore a more quotidian and boundaryless environmentalism enacted by employees at various levels, directly leading to incremental changes. Studying this type of activism requires an approach that moves away from the dichotomy between organisational resistance (the 'inside') and civil society activism (the 'outside'). It demands an openness towards a heterogeneity of activisms, not only demonstrations on the street, but also more mundane, everyday acts that can be seen as part of wider politics (Huault et al., 2014). Following Huault et al., we therefore find Jacques Rancière's (2015, p.35-36) elaborations on 'partaking' incisive for understanding employees' environmental activism - a conception we merge with recent contributions of 'prefiguration', i.e. political actions with direct effects (e.g. Farias, 2017; Kokkinidis, 2015). With Rancière we develop the concept of 'prefigurative partaking' to analyse a form of everyday environmental politics 'in which desired outcomes are created in the here and now rather than projected into the future' (Reedy et al., 2016, p.1554). It is an approach that affords us to recognize how actions potentially can come about anywhere, 'by the competence of all' (Rancière, 2016, p.114), and not just by politically adept persons in politically fecund spaces.

\section{Activism and politics in organisation studies}

\section{The 'inside' perspective}

Organisational scholars have studied how organisational members misbehave and resist managerial control mechanisms since the inception of the field (e.g. Pondy, 1967; Schmidt \& Kochan, 1972). Particularly in the 1970s and 1980s, this was often informed by Marxian analyses, problematising the structural power relations between classes in the workplace (Braverman, 1974; Burawoy, 1979; Thompson \& Ackroyd, 1995). Since the 1990s, authors have been increasingly interested in what has been called 'micro-emancipation' (Alvesson \& Willmott, 1992), emphasising 'various forms of everyday emancipation which people mobilize to challenge managerial domination' (Huault et al., 2014, p.27). Authors have discussed a range of often informal resistance tactics occurring in the workplace, such as cynicism (Fleming \& Spicer, 2003), humour (Collinson, 2002) and sexuality (Brewis et al., 2014). Given the 'quiet', piecemeal nature of these everyday political acts in the workplace, they have also been labelled 'infra-politics' (Böhm et al., 2008; Scott, 2005). This move towards 'infra-politics' reflects recent post-structural affirmations of diverse and productive power relations happening at work (Courpasson et al., 2012; Daskalaki \& Kokkinidis, 2017), showing that less antagonistic political performative actions are possible within corporate settings (Parker \& Parker, 2017).

Aiming to go beyond Marxian analyses, the 'micro-emancipation' literature has been firmly focused on the resistance of workers, employees and managers against managerial and hierarchical modes of domination. This has often resulted in wider political debates and struggles being ignored (Scully \& Segal, 2002; Spicer \& Böhm, 2007). Chief amongst these broader societal struggles are environmental issues, which previously have been neglected by organisational scholars. While it has taken a long time for Shrivastava's (1994) plea for authors in our field to recognise organisations' often destructive relationship with the environment, there is now an increasing literature in organisation studies on environmental issues (Banerjee, 2003; Goworek et al., 2018; Wright et al., 2011). However, there is still a predominant view that environmental politics is happening outside (corporate) organisations.

\section{The 'outside' perspective}


It is often taken for granted that activism is located in the realms of civil society, conceived as a space of 'contentious politics' (Tarrow, 2011) from which citizens can pose critique against public and private organisations. This critique is commonly identified to be in opposition to something, an 'anti' so to speak. Be it anti-capitalistic (Dixon, 2014), anti-identitarian (Eleftheriadis, 2015), anti-hierarchical (Kaufman, 2016), anti-militaristic (Sørensen, 2016, p.3), anti-racist or anti-colonialist (Luchies, 2015), followed by disruptive troublemaking, as in the Occupy movement (Jaffe, 2016).

The environmental movement, in particular, has been a growing phenomenon. Many transnational environmental activist groups, such as WWF, Greenpeace and Friends of the Earth, challenge state institutions and corporate organisations to address environmental issues such as pollution and climate change (Wapner, 1996). Given these environmental movements' potential to disrupt organisations, scholars have increasingly studied how (corporate) organisations engage with such 'troublemakers' (Banerjee, 2003; Bertels et al., 2014; Crotty, 2006; MacKay \& Munro, 2012). Hence, environmental activism is analysed as an external force that impacts, or enters, organisations from the outside (Bansal et al., 2014). Den Hond and de Bakker (2007) argue that activist groups can be either radical or reformative and often target more than one firm to accomplish change. With further interest in how managers respond to external activism (Waldron et al., 2013) showing that corporations handle environmental activists as stakeholders differently depending on the reputation and status of the activist group (Perrault \& Clark, 2016), there is either 'recognition and integration of environmental concerns into a firm's decision-making process' (Banerjee, 2002, p.177) or activism is treated as a threat that needs to be handled to calm the waters (Zietsma \& Winn, 2008).

\section{Blurring the 'inside' and 'outside'}

Despite the disconnect between the two strands of literature exemplified above, there are some studies that seek to bridge the 'inside' and 'outside' perspective with a focus on activism, suggesting that it has more dispersed forms and targets (Jacobsson \& Sörbom, 2015; Maxey 1999, Reitan, 2010). Hysing and Olson (2018) show how public sector organisations can be transformed from the inside, as public officials act strategically from within these institutions to incrementally change public policy in line with the values of global environmental movements. What they call 'green inside activism' is a form of activism that is closely connected with the wider environmental struggle globally, and seen as more 'pro' than 'anti'. That is, in contrast to civil society-based environmental movements struggling against public or private organisations in calls for wholesale changes, 'green inside activism' concerns changing these (often large) institutions incrementally from within. This can directly involve transnational environmental activist groups, as they collaborate closely with state institutions and corporate organisations (Dahan et al., 2010; Wapner, 1996). As in WWF's Green Office programme, where organisational members have been empowered to act pro-environmentally (Uusi-Rauva \& Heikkurinen, 2013).

Meyerson and Scully's (1995, p.598) seminal article on 'tempered radicals' describes organisational members who are 'outsiders within', that is, individuals who 'may be playing parts in movements bigger than themselves and their organizations'. These 'tempered radicals' can address race, gender and other justice issues by working in sometimes very mainstream settings, following a tactic of small wins and local, spontaneous and incremental action. Similarly, Creed and Scully (2000, p.391) show how marginalised employees, as members of the lesbian, gay, bisexual, and transgender, queer, intersex (LGBTQI+) community, are 'micromobilizing moments of social movements', directing transformation in workplaces. In relation to sustainability, Wright et al. (2012, p.1461) explore how managers perceive climate 
issues differently, one of their findings being the managerial identity as 'committed activist'. Similarly to studies of resistance within organisations (Alvesson \& Robertson, 2015), these studies nevertheless presume that complex identity work is a fundamental part of the transformational process (see also Allen et al., 2015).

These and other contributions - some of which are based in the fields of business ethics and Corporate Social Responsibility (CSR) - have indeed pointed to a blurring of boundaries between the 'inside' and 'outside' (Christensen et al., 2013; Hemingway \& Maclagan, 2004; Sonenshein, 2016). Yet, what has been underexplored is how mundane, everyday forms of action pursued from within corporate organisations can be conceptualized in relation to activist politics, one being environmentalism and the quest for green transformations. That is, when employees and other organisational members engage in actions at work in line with their personal convictions for a cause, how do they constitute moments of politics? To complement the ongoing bridging between organisation studies and social movement studies, we thus wish to develop a different approach that can afford to take into consideration contemporary turbulent political landscapes and dispersed expressions of environmental activism (Dauvergne, 2016; Jamison, 2001; Scoones et al., 2015). To accomplish this we borrow a concept and practice from the world of social movements, namely prefiguration, merging it with the political philosophy of Rancière, and applying it to our study of the corporate sphere.

\section{Theoretical Frame: Prefigurative politics and partaking}

The starting point for our approach to conceptualising environmental politics is the understanding that by engaging in direct action (e.g. see Doherty et al., 2003; Epstein, 1991), anybody anywhere can get involved in activist politics, even by piecemeal, ordinary, everyday efforts, which, prefiguring a certain political aspiration, aims to create change in the here and now (cf. Chatterton \& Pickerill, 2010; Haug, 2013; Maeckelbergh, 2011, p.4; Routledge, 2012). Hence, activism as 'prefiguration' is conceived to thrive on values rather than 'instrumental efficiency' (Leach, 2013, p.1004), and to have immediate effects due to political 'ends' being directly created through their 'means' (Yates, 2015, p.1). Prefiguration thus follows a 'political process that allows experimenting with alternatives in practice' (Reinecke, 2018, p.1), something Horton (2006, p.41) pedagogically clarifies in a study of the bicycle, suggesting that 'green materialities' facilitate a living out and embodiment of a personal environmental politics in the everyday. Grassroots social movements have thus increasingly engaged in prefiguration by a do-it-yourself (DIY) ethics (Moore \& Roberts, 2009) that will 'just-get-on-with-it' (Reedy et al., 2016, p.1563), transforming what is within their grasp. 'Transformation' is thus to be more incrementally understood, a bit similar to how 'resistance' lately has been studied - 'not as a situated struggle against sovereign power and authority, but as a transformative force that is distributed across spaces and times' (Daskalaki \& Kokkinidis, 2017, p.1304).

There is some emerging interest amongst organisational scholars in prefigurative politics. Kokkinidis (2015) illustrates how three workers' collectives in Greece engage in horizontal, egalitarian and inclusive practices of self-management that involve workers immediately and directly. According to Farias (2017, p.579), prefiguration is shaped by 'praxis rather than ideology', where organisational members can get involved directly in a political movement 'in which desired outcomes are created in the here and now rather than projected into the future' (Reedy et al., 2016, p.1554). In her ethnographic study of Occupy London, Reinecke (2018) studies protesters' encounters with homeless people, examining the organisation of prefigurative politics in civil society. Sutherland et al. (2014) and Haug (2013) provide 
empirical illustrations of how this DIY culture is about creating 'free' and horizontal spaces without obvious organisational leaders. Notably, horizontal organising is in these studies identified either within a social movement or an intentional community.

Such grassroots, anti-hierarchical and self-organising ways of living - seemingly without being dominated by more powerful social and political institutions - have been very influential in prefiguring alternative organising (Chatterton \& Pickerill, 2010; Parker et al., 2014). Prefiguration therefore exemplifies an activism that is based on more immediate, autonomous and grassroots organisational actions than those used by formally institutionalised political movements (Böhm et al., 2010). The key concern to accomplish 'alternative' organising is a radical democracy and fundamental equality allowing partaking by anyone who is in some way affected by a decision (King \& Land, 2018). Similarly, prefigurative politics can transgress the boundaries of what Jacques Rancière calls 'the police order' (Rancière, 2016, p.114; Rhodes et al., 2018), i.e. existing, preconceived and institutionalised boundaries of politics that are organised and fixed (Rancière, 2003). This 'policing' of politics that Rancière criticises is clearly visible in the narrow realms of party politics, but also extends to what is commonly understood as more radical, grassroots politics. There too, activism often follows routinised, sometimes narrow, practices (Sutherland et al., 2014), which Rancière would not associate with 'politics proper', since that requires continuous transformation by how new 'ways of being, seeing and saying' are invented (Corcoran, in Rancière, 2010, p. 7).

Prefiguration bears more than a passing resemblance to Rancière's (2016) method of equality. 'Equality' is for him an axiomatic principle that makes it possible to assert intellectual solidarity to study how 'anyone' can begin, speak up and enter the political stage (Ibid., p. 114). He argues that politics often instils a relationship of dependency between those with the knowledge of inequality (politicians, activist leaders, academics) and their followers (Rancière, 1999; see also Sutherland et al., 2014). Hence 'equality is not given, nor is it claimed; it is practiced, it is verified' (Rancière, 1999, p.137). Instead of embracing activism by starting with the premise that an unjust inequality between people, groups and societies has occurred (Pellow, 2000), it should be approached by an affirmation of equal 'partaking' (metexis) (cf. Rancière, 2015, pp.35-36). Politics as partaking is thereby a boundaryless action (arkhêin), and not a quality within subjects, and not confined to specific organisations (Ibid., p. 36).

How, then, can we apply Rancière's method of equality to the study of environmental politics within a polluting company? First, we need to assert 'the competence of all', in order to study how 'anyone' can speak up and enter the political stage (Rancière, 2016, p.114). Second, we will need to recognise political moments as something else than acts of resistance, that is, as contingencies that arise when 'the order of the sensible' is disturbed or disrupted (Huault et al., 2014, p.23). And third, this demands an attentiveness to actions that respond to 'dissociation', i.e. ruptures in what was previously thought (Rancière, 2014, p.75). Conclusively, our analytical emphasis is on actions rather than beings, or even identities, where 'partaking' gives rise to political moments. Politics is consequently to be studied as a boundaryless, dispersed movement of uncalculated sayings and doings that follows uncharted paths.

Following Rancière, it is not so important to identify the 'internal activists' (Wickert \& Schaefer, 2015, p.107; Girschik, 2018) or 'organizational activists' (Spicer et al., 2009, p.552) who are perhaps engaging in productive resistance (Courpasson et al., 2012). Instead, 'partaking' opens a new way of studying how people pursue politics by sayings and doings. Here we should note that, for Rancière (2014, p.12), it is a 'prejudice that speech is in opposition to action'. Similarly, it has been argued that there is a corporeal performativity, or embodied 
prefiguration, attached to speech, putting into doubt the separation between talk and action (Esterhammer \& Dick, 2009; see also Felman, 2002). This leads us closer to "prefigurative partaking' as a concept useful for the study of sayings and doings that are conceived as dispersed political actions with direct transformational effects - even within the corporation normally not associated with prefigurative activism.

Specifically, this merger of prefiguration and partaking points us to forms and processes of everyday activism that are often not heroic, but incremental and consisting of comparatively small efforts arising out of dissociation and ruptures in the taken-for-granted, i.e. more direct and democratic challenges of consensus processes (Rhodes et al., 2018), including the realm of what we normally associate with politics. In contrast to Farias' (2017) emphasis on emotions and intimacy in her study of hospitality towards the Other within a porous intentional community, we therefore suggest that prefigurative politics also can thrive in more impersonal and boundaryless ways. People do not necessarily have to develop affinities with each other, but with a cause shaped by a boundaryless knowledge movement, which opens up for an analytical acknowledgement of anyone's ability to partake politically, regardless of their hierarchical position. It points to an exploration of more horizontal and anonymous relations, which, in comparison to Huault et al. (2014), do not necessarily correlate to collective empowerment or emancipation processes. Prefigurative partaking is hence an important aspect of organisational politics that encompasses wider political and social issues - such as environmental degradation - within the organisational setting of everyday life at work.

\section{Methods}

\section{Empirical setting}

The utility under study, Ordalia, was founded in the early $20^{\text {th }}$ century by a state government to secure industrial and public needs for electricity and heat. Ordalia's average turnover has been in excess of $€ 14$ bn each year between 2012 and 2017, employing an average of 27,000 people across Europe. The company develops, constructs, operates and sells electricity and heat with a mixed portfolio of coal and lignite, gas, nuclear, hydropower and large scale renewables.

The research has been limited to Sweden and the UK, with one of the authors visiting the various wind power development units of Ordalia (see summary in Table 1). It started with a short pilot study to build trust in 2012/13. A non-disclosure-agreement between the company and the researchers was agreed in 2014. The bulk of the empirical material was collected between 2014 and 2015. The lead researcher was given a personalised entrance card, often appearing as if she belonged to the company. It was thus easy to be included in the daily office chats, while the participants, according to the research ethics, were required to be informed about the presence of the researcher. In October 2015, the two authors also interviewed the Senior Vice President of Strategic Development via Skype. The main researcher also attended meetings, videoconferences, a Friday kettle bell exercise session, and had informal conversations during coffee breaks, lunches, post-work beers and one dinner. The progress of the study was reported to the company's environmental director, who then reported the findings to the board of directors.

\section{< Insert Table 1 here >}

$<$ Insert Table 2 here > 
All interviews were voluntary. Employees at different levels and with various work tasks within Ordalia's wind power development units were invited by email or by direct contact in the office (see Table 2). The interviews were about one hour long, semi-structured and transcribed, and were individually designed depending on the specific work tasks of the interviewee. That is, a wind power project manager was expected to talk about different environmental aspects to an ocean analyst or financial analyst. Generally, we covered several topics, from personal history, professional background, everyday work tasks, career situation, geographical location, engagement in corporate leisure activities and relation to colleagues locally and in other countries. Our study was not originally designed to address issues of equality in the Rancièrian sense framed in this paper. Hence, in contrast to Courpasson et al. (2012, p.806), we did not pose specific questions about 'resistance' per se. Rather, the interviews aimed at getting closer to the employees' environmental interests, such as knowledge and opinions about environmental problems, energy sources, climate change and wind power. We also asked about experiences of meeting external activists, opinions about the media picture, examples of crucial environmentally hazardous events, employee environmental initiatives and Ordalia's overall operations, core values, ethics and environmental management. All the interviews were focused on environmental issues, but some interviewees chose to express additional opinions about other 'political' topics, such as gender issues and Thatcherism (Fieldnotes, 2015-01-21).

The research design aimed to provide details and rich examples important for a qualitative study that seeks depth about a specific topic (cf. Coyne, 1997). Even though a rigorous targeting of specific participants sometimes uses 'saturation' as a quality criterion (Morse, 1995), we chose not to follow such a methodological practice (O'Reilly \& Parker, 2012). A richer variety of prefigurative partaking, and its opposite, would only have been possible to explore with extended access to other units at Ordalia, and an exhaustive account of environmental activism at Ordalia is not our aim. In fact, one can say that we have studied a minor phenomenon at Ordalia. In studies of employee minorities, it is nevertheless crucial to purposefully talk to engaged employees to learn about their potential insider activism (Creed \& Scully, 2000; Girschik, 2018; Wickert \& De Bakker, 2018). This is a common approach in studies interested in theory-generation rather than sampling issues (see Courpasson et al., 2012). It is also close to Rancière's more elaborate 'poetics of knowledge', which seeks to bridge between disciplines so as to work close to the research participants and a specific theoretical topic (Guénoun et al., 2000). Keeping in mind that 'the relationship of the researcher to the field contributes to the construction of it' (Melucci, 1995, p.42), we thus stayed close and open to the research participants with Rancière's method of equality in mind.

We also needed to be able to analytically grasp the extensive empirical material, including a co-analysis by the two authors. The transcribed interviews were coded twice, and partly translated, to explore different layers and details. The analysis required an intense period of reading and re-reading transcripts, monthly repeated discussions between the authors, and iterations between theory and empirics (Fereday \& Muir-Cochrane, 2006; Huber \& Brown, 2017). For the first step of coding, we used colour codes to highlight three sometimes overlapping themes; green for descriptions of environmental problems with wind power; blue for how employees meet external resistance towards wind power and for the focus of this article; red for employees' confrontation between knowledge about environmental problems and everyday experience of environmental engagement at Ordalia. After the first step of coding, we tried to come closer to dissociation (Rancière, 2014, p.75) and characterising themes of 'prefigurative partaking' by means of a second order of codes. Dissociation arises out of the confrontation we first noted, and can be further understood as an experience of disruption. Our analysis should thus not be misunderstood to hone in on ruptures that are created by the 
employees in acts of resistance (Karfakis \& Kokkinidis, 2011). We rather see the political act as that which follows upon dissociation in the attempt to heal ruptures. A healing process consisting of sayings and doings that accomplish a productive uncharted and direct transformation.

After new discussions and readings, we finally agreed to explore six second order codes of prefigurative partaking: aspirational (envisioning the future), individual (micro-managing one's own impact), professional (using one's professional knowledge), critical (voicing ruptures), loyal (accomplishing the green employer) and communal (fuelling interest among colleagues) prefigurative partaking (see Figure 1). Inspired by Czarniawska (1997), we present the details of these as a narration, consisting of a compilation of these characterising themes that are taking place at different times and places. We do not hide the corporeality of sayings and doings, while also shedding light on a movement of 'actions'. Importantly, during this analysis we excluded other potentially interesting effects of utterances and rhetorical talk within a known 'ethos' and profession (Billig, 1995) to rather illustrate how one employee can contribute to different forms of prefigurative partaking (second order codes).

$<$ Insert Figure 1 here>

\section{Prefigurative partaking at Ordalia}

\section{Aspirational prefigurative partaking}

The $4^{\text {th }}$ floor is definitely crowded with wind people. It should just be brimming, look at this house! Renewable people! There's no pride today in what we're doing! And I don't know if it's because we're now a bit tarnished with ....... don't know, non-success or whatever? I think it's fair to say if the company fostered a bit more pride in what we're doing, then maybe we'd also seek more. You know, have a bit more atmosphere around working for something hard.... The ideology is really blossoming now! (Natalie, 2014)

When Natalie says top-down management should be prouder and engage more to create an 'atmosphere', the utterance prefigures a 'renewable people'. Not a people imagined to come, but one that is already there, unseen and neglected. Repeatedly, others agree with this desire for future top management engagement with those working with renewables, even if they should not be used as 'a kind of green wash for the company' (Eva, 2015; see also Desiré, 2012). As Lennart (2013) adds, 'the fundamental reason for why I work must be there, some sort of environmental connection, strong connection to the environment'. It is a human-environment relation that is preferred, to establish coherence between 'beliefs and also with what you are doing' (David, 2014). Several others agree, saying it would be very difficult to work with anything other than renewables (e.g. see Richard, 2014; Eva 2015). Drawing on her previous experience as an employee within another utility, Natalie (2014) warns us:

Visiting the lignite operations was 'like visiting hell because really I saw this guy, he was carrying something heavy on his shoulders completely covered in soot and the whole power plant was just nasty and there'd been this horrible incident (...) a guy had fallen in, into some hot material I don't know really, something left over in the process and he actually burned to death. Oh that sounded so horrible, he fell in, he sat halfway buried and burned to death slowly...slow roast, they couldn't get 
him out (...) How can you go back and work on such a horrible project? No, that has to be avoided to all costs.'

David (2014) emphasises that 'it's nice to be part of the solution rather than part of the problem'. It is by prefiguring renewables as the future that Ordalia is imagined to 'take a lead on getting the emissions down' (Jane, 2014). Aspirational prefiguration calls out for grassroots change and newness. '[W]e as a world need to look at things from the grassroots and just completely overhaul the way we do things', Liz (2015) proposes. Richard (2014) adds that 'instead of economic growth we have to have sustainable growth'.

Besides being visionary, several utterances strongly support what Ordalia is already doing. Rosmarie, whom we meet frequently, adds to this by proudly wearing a badge on her collar depicting wind power turbine blades and always talking warmly about ongoing and future wind power projects. Once, during a coffee break at the Swedish headquarters, we meet a fellow, male wind power fan - who, like Rosmarie, has blades on his collar - and they start chatting about their mutual vision for wind power. Wind power is prefigured as the future 'where things are happening, and where one can make a difference and contribute to, yes what can we call it, a better world or something' (Lennart, 2013). And it is of importance not to 'aim for the lowest level of environmental engagement, rather the highest level' (Fredrik, 2012). Pia and Rosmarie often speak about this ambition when we report back about the research, but admit it is very difficult to gain internal support for everything they would like to accomplish top-down.

\section{Individual prefigurative partaking}

There is a general aspiration to pass environmental engagement on, via both the intranet and physical meetings. Imposing green thinking on others is seen as problematic since this 'doesn't go down well, it comes across as preaching' and it 'doesn't make life easy'. Rather, secret individual do-it-yourself approaches unfold to sort others' garbage when they have used the wrong bin in the office kitchen (Eva, 2015). In comparison to the Swedish headquarters, where recycling bins have been implemented as part of the office design, the offices in the UK have more haphazard recycling systems. During a dinner with the UK office manager, we are inclined to think he cares more about gender issues than environmental issues (Fieldnotes, 2015-09-24). Tellingly, Liz (2015) confirms that she had to put up recycling bins on her own initiative in one of the other UK offices.

I just set the bin up, I didn't ask anyone I just did it. I think most people kind of, if you make something easy for people they adopt it don't they, so I think recycling is quite an easy one really, there's more that we could all be doing, definitely, you know like having the heating on when the window's open, well that's just silly so things like that...

\section{<Insert Figure 2 here, photo of designed recycle bins at headquarters>}

Another example of an individual DIY approach is Olga's (2014) everyday walk up the stairs in the London office to the first floor, instead of taking the lift. Her behaviour is broached at the well-equipped toilet, where deodorant is frequently used. 'I feel guilty', she tells us and Natalie. 'Do you have much to feel guilty about?' Natalie retorts. 'We always have things to feel guilty about, don't we?' (Fieldnotes, 2014-11-07). Cecilia also climbs the stairs in Sweden, but eleven floors and mainly for exercise after lunch, adding that it saves electricity too (Fieldnotes, 2013-10-29). Others are voluntarily micro-managing their own environmental impact at work by turning off their computer screens every night (Richard, 2014). Beatrice and 
Olga ask us to forward their wish that Ordalia introduces more top-down initiatives for similar everyday energy savings. Taking prefigurative actions on one's own is, however, preferred by Eva (2015): 'I'll go by train to places and if people ask, I'll say why I go by train, it's that sort of thing'. Laughing and leaning back in the chair, Eva plays down her actions as 'armchair activism'.

\section{Professional prefigurative partaking}

Prefiguration can also occur when employees merge their will to improve their impact on the climate with their professional knowledge, but are reluctant to engage in violent actions. Hedvig (2013) questions whether it is 'right to take militant action to make a change? No, I don't think so. That is why I wanted to engage differently, with knowledge, really' (Hedvig, 2013). This is repeated on several occasions not only in terms of their work with renewables, but also their attitude towards the lignite operations. Nils, an external environmental consultant involved in Ordalia's wind developments in Sweden, exemplifies that if he 'can be involved and get a say then [he would] have a bigger influence than if [he] would be on the outside, something like, say, sending in appeals as a private person' (Nils, 2013). There is thus a strong belief in changing the world via professional work, spanning from going out on extra excursions to make sure that there are no oil spills from Ordalia's constructions (Kirsten, 2014), to taking horse riders out on tours around wind power plants to convince them of their compatibility with equestrian sports (Liz, 2015). Other examples of extra actions beyond what is required by topdown management include: more detailed life cycle assessments; waste management on site; delaying new wind projects due to spawning seasons; and to 'push environmental conditions on to contractors and to justify environmental costs' (Kirsten, 2014). Here the professional prefiguration relies on the authority of being a big player in the market for large-scale wind power projects. Nevertheless, a dejected Peter (2014) mentions that Ordalia misses out on its capacity to empower the employees as professionals in renewables, which is why he took it into his own hands but failed:

'We don't have any magazines that cover or we don't have any office posters showing environmental things (...) or big things happening. I don't think there is much engagement from the office point of view, you don't see much (...). All you see is a couple of miniature wind turbines otherwise you don't know what the business is. I've asked to put a TV screen at reception showing our [wind power], I've experienced when I'm always visiting one of our competitors, they were more proudly showing off the project they were building (...). I've asked and they took 6 months to put something up and then it disappeared after 2 weeks (...), just disappeared for no reason. (Peter, 2014)

There can of course be many reasons why the TV screen next to the receptionist was tuned into something else, commonly some news channel. The lack of symbols for wind power exemplified at the UK headquarters, did, however, spur professional partaking to break through, in an attempt to respond to the rupture in what was actually done and what was shown - to make the everyday work with the renewable projects more visible. In Sweden, the wind power development office is on the contrary filled with symbols at the individual desks, and in the common space there is a huge Lego wind power turbine used by visiting children of the employees. 
$<$ Insert Figure 3 here, photo of offshore wind power at Ordalia's reception North office >

\section{Critical prefigurative partaking}

In comparison to aspirational, individual and professional partaking, there are examples of more angry and critical prefiguration that is openly negative, especially about the lignite operations.

'I actually think that Ordalia has done a lot of stupid things in this ReNew [pseudonym] affair and in retrospect, the whole tour of Europe, really, it was much better when we were, when we kept to Sweden and the Nordic countries'. (Julia, 2013)

The earlier move to lignite is deemed to be 'strange' (David, 2014) and 'bizarre', since it is 'the dirtiest of the dirty coals in a totally different market' (George, 2015). The lignite is still believed to be lucrative for Ordalia, which is why those profits are envisioned to be used for new technologies at the same time as 'it's better just to move away from there as soon as we can, without affecting the communities that live around that area' (Natalie, 2014). Bodil (2012) suggests that it should 'be phased out', even if Ordalia's official position is that 'all energy resources are equally valuable and one has to have all of them in one's portfolio'. She suggests that 'we should not have coal power. We should phase it out. That might be something one shouldn't say, something which is not politically correct, but ...eh...I think so' (Bodil, 2012). It is not only lignite that is imagined as being sold off or phased out, but, as Martin (2015) envisions when the recorder is turned off, Ordalia should also close down coal operations, as Greenpeace demanded. Olga (2014) confrontationally prefigures the same from the London office, arguing 'well we should just get rid of the lignite, shouldn't we, just close it all down'. Adding that due to the complexities with closing down an operation employing a lot of people, 'Ordalia really has to have incredibly clear strategy and defensible arguments as to why things need to change and we need to say, even though we are a progressive, idealistic company, our main focus is renewable energy' (Olga, 2014).

Even though the wind power operations are celebrated, there remain critical statements of dissociation leading to strong questioning of the organisation's overall environmental engagement. The travelling habits, for example, are regarded as 'crazy' from a $\mathrm{CO}_{2}$ perspective (Eva, 2015), and Ordalia's environmental engagement overall is not recognised as visible (Anna, 2013). Hedvig (2013) thinks the 'core values, both environmental and safety issues, should have been more supported'. Instead, 'we get to solve a lot of things ourselves'. Others find it 'really hard to understand Ordalia's environmental management, because 'I've tried and I've found it really hard to understand who manages what' (Kirsten, 2014). Kirsten remarks that nobody cares about everyday work practices, and wishes herself to 'get more involved in our travel' habits and waste management. She adamantly proposes that this would 'make people think more about their travel and offsite operations and things' (Kirsten, 2014). Besides, there are 'recycle bins [in the London office] but all the waste gets taken into just a big bin at the bottom, so there's no recycling (...) if we really cared we would try and do something about that' (Kirsten, 2014). Due to similar issues, Beatrice (2014) adds that her 'view of Ordalia's engagement with the environment gets worse and worse' over time. Olga is even more elaborate in her critique:

You shouldn't go through life causing a negative impact, I think if you are just happy to sit in the upper echelons of a European utilities company with your head in the sand with regard to environmental issues then you shouldn't be there, do you 
see what I mean? It's not so much head in the sand sometimes, there are some people that think about the bigger picture and there are some people that just don't think. (Olga, 2014)

\section{Loyal prefigurative partaking}

Despite existing strong negative critique, there are re-occurring loyal expressions of 'faith in the organization' (Helen, 2015). Alongside utterances of faith and belief in the organisation, it is acknowledged that 'Ordalia has also got its problems' (Karl, 2013). Some 'screen out' what happens outside the wind power operations (Julia, 2013), pointing to the path-dependency of energy technologies (Karl, 2013) and the fact Ordalia 'hasn't got the greenest track record of companies' but at least tries to turn itself around (Felicia, 2015). Loyal prefiguration is thus about saying something critical followed by a disclaimer, as David (2014) does when he explains that Ordalia cannot 'just jump and do as an organization like Greenpeace demands because it is a big company' with economic responsibilities, where a transition to renewables would not be possible 'without having these other units'. Ian points out a clear 'anti' in the form of 'an elephant in the room', saying that even if Ordalia is 'doing the right thing' by 'going down this renewables route', in Germany, 'Ordalia owns two of the most polluting power stations', and 'everybody who knows the industry knows that it is there' (Ian, 2014). Prefiguring a change loyally, Ian (2014) backs this up with a re-occurring disclaimer: 'It's the same for other companies as well, it's a reality of energy, and we have to have it because we're at the start of a different energy' situation. A similar argument is reflected in discussions with Miriam, director for wind developments in Sweden, at whose desk there is a comic strip of typical arguments against nuclear, oil, coal and wind:

\section{< Insert Figure 4 here, photo of comic slip >}

Even though implicitly critical, loyal partaking concerns prefiguring a positive relation to Ordalia, with sayings such as: '[w]e work in a way that I think I can stand for' (Cecilia, 2013), 'the soul of Ordalia is a positive one for the environment' (George, 2015) and '[ $t$ ]here is nothing that Ordalia does that I feel that I could not, I do not think everything is handled perfectly, but there is nothing that I feel is totally condemnable' (Desiré, 2012). The loyal statements prefigure Ordalia's core as genuine, being based on green ambitions, and often seen as misrepresented by the organisation itself, for example in criticising huge discrepancies between the true green intentions of Ordalia and the awkward PR campaigns generated by the CSR unit that fail to show what the organisation and its employees are really doing (Desiré, 2012; Bodil, 2012). Desiré (2012) paints her own, what she believes to be more accurate, green picture of Ordalia, similar to how Julia (2013) emphasises 'that Ordalia is unfairly criticized in newspapers' and Jane (2014) protects her employer at a dinner party:

$[F]$ or the first time someone felt sorry for me working in Ordalia because of the media attention and everything, headlines and everything else, so negative, but I mean I don't know, I'm not fettered by it and that's because I know that Ordalia are doing quite a lot of good things and the media picture is not the real accurate and true one.

\section{Communal prefigurative partaking}

Having personal conversations to promote wind power to strangers, friends and family members is something some of the employees do, especially in the UK. It is easier in the UK than in Sweden, where 'everyone is opinionated' and the external critique is immense (Fieldnotes, 2014-10-03). The British employees also take conventional political actions by 
signing Greenpeace petitions, paying membership fees to the Green Party or the campaign ' 38 Degrees', and promoting wind power or other environmental improvements to their local MPs (Members of Parliament). Sometimes, Ordalia UK incorporates the employees as citizens by asking them to write privately to their MPs. At other times, the employees do so on their own initiative. Richard (2014) is even active in the Transition Town movement, which he admits is only loosely connected to his environmental ambition at Ordalia. Organised environmental actions have also been arranged outside the office for the employees. Some at the Southwest office have cleaned nearby beaches, and there is a desire to do the same close to the London office. Lest we forget, volunteering for the research project behind this article also exemplifies communal prefiguration, by virtue of how it spurs uncharted environmental discussions. A total 'culture change' is deemed necessary (Martin, 2015), to enable going beyond the traditionalists (Desiré, 2012). It would even be 'worth annoying some people to get the results' (Martin, 2015). David (2014) imagines that environmental get-togethers, perhaps by going out in nature together, could spur his UK colleagues to become more 'Swedish-like'. He suggests a trip to the Arctic region and regular meetings on Fridays over coffee and cake to watch documentaries about climate change (David, 2014).

In a less organised way, communal prefiguration was suddenly fuelled when a photo from a site visit to the German lignite operations was passed around. Some employees were very surprised Ordalia had lignite operations, since they were used to thinking of the renewable operations in the UK only. Employees thus came together to express mutual disgust with the polluting operations. Another time in the London office, four employees share nostalgic flashbacks from 'the old times', when, as they say, Ordalia UK was run by activists. Together they contemplate how the green engagement looked when things were less 'corporate' (Fieldnotes, 2014-10-23). Stephen also talks about his visit to the Southwest office, where his colleagues complained to him about the fruit basket being delivered all the way from London (Fieldnotes, 2014-10-15).

\section{Discussion}

The above empirical narrative has revealed different modes of prefigurative partaking, in the form of everyday sayings and doings, as enacted by employees at Ordalia. We will now discuss how these everyday actions can be thought of as environmental activism transgressing organisational boundaries, theorising environmental activism pursued at work. We argue that prefigurative partaking occurs as organisational members respond to moments of dissociation (Rancière, 2014, p.75), which leads to a questioning of parts of the established order. This questioning is driven by an attempt to heal ruptures, i.e. the irritating experience of disturbance, by enacting direct, incremental changes based on the realisation of a new world in the here and now. As our empirical analysis has shown, the most important elements in prefiguration are: an ongoing 'movement' based on the dissemination of knowledge about environmental problems and a dispersion of activism (Scoones et al., 2015); the situatedness and instant creation of a 'new world' at work and perhaps even beyond; and, in the spirit of Rancière's principle of equality, a radically horizontal form of organising that cuts across established organisational hierarchies, be it at Ordalia or between Ordalia and others. What becomes visible is how activism is becoming more dispersed and boundaryless in the current turbulent political landscape, without being confined to, and limited by, what is called 'civil society'. Environmental activism, with our concept of prefigurative partaking, is testament to a more fluid and generous space of political action. We will now discuss three aspects of the 
conceptualisation of prefigurative partaking in more detail; namely incremental change, horizontal organising and boundaryless activism.

\section{Prefigurative partaking and incremental change}

All six forms of everyday actions illustrated in our narration are testament to unassailably big environmental problems generated via Ordalia's operations, which act like 'an elephant in the room' (Ian, 2014). Contrasts between employees' knowledge about environmental problems and these operations result in dissociation. Rancière (2014, p.75) calls this the sensible being disrupted; what is thought and sensed is deeply disturbed. In response to this dissociation, we observed the micro-management of employees' own behaviours, i.e. individual prefigurative partaking. But individual responses are not enough. Ordalia's 'dirty' lignite operations are portrayed by the employees as path-dependent, market-driven and even in need of something bigger and more abstract attached to the everyday actions, such as 'faith' (Helen, 2015). For this reason, critical prefigurative partaking stands out, thriving on a strong contrast between acquired knowledge about environmental problems and Ordalia's polluting lignite operations. Critical prefigurative partaking voices ruptures in a more aggressive and confrontational way (Karfakis \& Kokkinidis, 2011), with desires to phase out or close down huge lignite facilities employing thousands of people. The employees quickly turn an 'anti' into a 'pro' in efforts to accomplish constructive transformations.

One could read these prefigurative calls as either naïve or cynical (Fleming \& Spicer, 2003). Yet, our findings suggest that environmental actions are positively embraced and not spoken about as if in 'denial' (Allen et al., 2015). Indeed, it was expressed as crucial to be part of the solution (wind power) and not the problem (lignite operations) (David, 2014), exemplifying how employees can work for a cause in the here and now. Meyerson and Scully's (1995) concept of 'tempered radicals' is fitting here, as the Ordalia employees we studied were ambiguously supported by parts of the organisation and external environmental movements alike. Their actions range from small, individual voluntary DIY approaches at work (Doherty et al., 2003; Eleftheriadis, 2015; Moore \& Roberts, 2009), including walking up the stairs and sorting other's garbage, to creating facilitative structures without help from top-down management, such as providing recycling bins.

Hence, we found that everyday actions unfold dynamically and lead to direct effects (Yates, 2015), but also to more uncharted multi-directional and diffuse transformations (see Reitan, 2010) that are piecemeal and less antagonistic (Briscoe and Gupta, 2016). There is consequently no clear opponent to counter or 'anti' to struggle with (Rancière, 2016, p.113), but efforts to 'alter' by 'screening out' and detaching from Ordalia's and other companies' polluting operations, by taking actions where possible leads to a more fluid and dispersed 'transformational force' (cf. Daskalaki \& Kokkinidis, 2017, p.1304). This shows how actions are more about doing than planning (Maeckelbergh, 2011), based on a fundamental impatience with a discrepancy between present and future. In our case, employee activism is thus to productively lead the way forward, mainly by enacting 'renewables' or 'the green' (Horton, 2006), nurtured by a will to change in the here and now (Eleftheriadis, 2015).

In line with existing conceptions of 'tempered radicals' (Meyerson \& Scully, 1995), 'insider activists' (Briscoe \& Gupta, 2016) and 'social change agents' (Sonenshein, 2016), we can hence understand how and why environmental activists choose to work in polluting organisations, being embedded in very contradictory organisational experiences. Analysing their sayings and doings with Ranicère's notion of equality and politics as partaking brings forth the formation of a vanguard position, exemplified in the proposal of a new route for Ordalia: renewables only. 
Similar to the aspirational partaking calling for 'a renewable people', critical partaking calls for a renewable Ordalia, showing both what it means 'to begin', arkhêin, and to break with the old and take the lead (Rancière, 2010, p.29). Why wait for someone who 'happ[ily] sits in upper echelons of a European utilities company with [the] head in the sand' and 'just don't think' (Olga, 2014)? This suggests the various direct actions, taken by employees, lead to incremental changes, even if system-wide alterations are nurtured and a wider politics invoked (Huault et al., 2014), especially in communal prefigurative partaking. Troublemaking civil society activism (Jaffe, 2016) is downplayed by the employees who question aggressive actions, by an affirmation of positive DIY changes at work that are 'pro' the environment. This is consequently a form of employee activism that anyone can partake in. It is an activism as superfluous to the hierarchical formal organisation as it is fake for those who police activism as a civil society phenomenon, as an underdog heroic act on the outside of polluting organisations.

\section{Prefigurative partaking and horizontal organising}

The basic Rancièrian (2015, pp.35-36) principle that anyone can get involved in activism via political partaking leads us to delve further into, not a bottom-up grassroots employee activism that still echoes a presumed struggle with top-down managerial hierarchies (Courpasson et al., 2012), but the echo of horizontal organising, a modus operandi of many social movement organisations (Farias, 2017; Leach, 2013). Our findings suggest that employees' uncoordinated prefigurative partaking was not narrow minded, but dynamic, plural and diverse; which Farias (2017) also observed in her study of an intentional community that continuously nurtured porosity via hospitality and new friendships. Similarly to Kokkinidis (2015, p.847), we thus experienced how 'diverse opinions flourish[ed] rather than being suppressed', and how everyday productive forms of criticism emerged via a freedom to speak up at work (Huault et al., 2014). Employees even seem to be ahead of their bosses in terms of environmental action, thriving on the contrast experienced between their own green ambitions and the top-down environmental inaction. An alternative form of organising consequently unfolds at Ordalia with 'non-universalizing, non-hierarchical, and non-coercive relationships and forms of power' rooted in 'shared ethical commitments' and diffuse collectivism (see also Parker \& Parker, 2017; Reitan, 2010, p.15).

The affirmation of possible horizontal organising, rather than bottom-up movements, does however rely on more than Rancière's equality principle, depending on the empirical access to various managerial levels and the empirical findings that follow. Even if critical prefigurative partaking points upwards with quests for a necessary change of a far too slow and unwilling managerial top, two of our closest research participants can be considered part of that very top (the Director of Off-shore Wind and the Environmental Director). Both engaged in green politics, historically and beyond their current professional roles, facilitated this research project and opened up the possibility of close investigation of their employer. Seeing the possibility to use our findings to accomplish more change towards a 'green Ordalia', both were also very aware of the fact that no matter what they did or said, it would always be interpreted as greenwashing. Hence, methodologically placing these two particular participants at the same level of 'partaking' as project assistants, coordinators, environmental managers, project managers and financial analysts, shows they also contribute to a horizontal, rather than bottomup or top-down, movement.

Related to this circumstance and in contrast to some existing literature, we generally encountered how organisational leaders avoided top-down attempts to regulate employees' (environmental) subjectivity (cf. Spicer et al., 2009). We did find some examples of a language 
of 'the good citizen' and what others categorise civil society engagement in environmental issues at work and beyond (Nyberg et al., 2013). For example, employees were sometimes encouraged to write letters to MPs to promote renewable solutions in a specific area. And instead of fearing or ridiculing it, some employees desired more leadership from their bosses in terms of environmental issues, by conceiving green issues opportunistically (Ekman, 2014).

\section{Prefigurative partaking and boundaryless activism}

Rancière's conception of politics encourages us to go beyond the separation between internal organisational resistance and activism in civil society, as well as the debate in organisation studies regarding more fine grained acts of resistance, via humour and cynicism, and radical revolutionary acts (Huault et al., 2014). Whilst Huault et al. explore previously neglected forms of 'emancipation' in the workplace with the help of Rancière, our approach is more attuned to the current turbulent political landscape and the emerging world of ephemeral, quotidian connectivity, networks and knowledge dissemination (Maxey, 1999). This implies an activism disconnected from a specific activist citizen, worker and target group (Mercea, 2016), focusing instead on an understanding of activism as distributed and dispersed, i.e. a boundaryless movement.

Although prefiguration has been criticised for having a tendency to depoliticise (Smith et al., 2017, p.101), our findings suggest a polarised view of politics as being there, or not, is difficult to maintain. Understood as prefigurative partaking, politics can be appreciated differently in the form of the everyday actions taken by a polluting corporation's employees, who thrive on their exclusive knowledge position, based on insights into both the core corporate operations and environmental problems. The employees are capable of a bridging that few others are, exemplifying a knowledge position that differs from say, Greenpeace, who can only criticise Ordalia for its negative impacts, with little interest in promoting the positive impacts as anything other than greenwashing.

Many employees we talked to expressed annoyance about how the company is portrayed by Greenpeace and other external actors in Sweden. Here, loyal prefigurative partaking thrives on contrasts between negative 'external' media pictures and positive 'internal' experiences of everyday environmental work at Ordalia. That is, the employees wish that the external 'talk' would correspond better with the actual internal 'walk'. In comparison to a long-standing negative media picture in Sweden, Ordalia has a genuinely green reputation in the UK. Loyal prefigurative partaking hence mainly happens in Sweden, whereas communal prefigurative partaking dominates in the UK, where British employees aim to improve the environmental record of the company, i.e. 'walk the talk'. This exemplifies 'rhetorical speech' seeking to assert a collectivity (Rancière, 2016, p.73), and perhaps even a search for affective ties based in praxis (Farias, 2017) and in situ experimentation (Reinecke, 2018). Consequently, whilst not shying away from the existing environmental problems at Ordalia, the environmental everyday actions result in loyalty. Hence, dissociation and ruptures (Rancière, 2014) are healed by direct actions, boundaryless insofar as they transgress the political spectrum (Meyer \& Tarrow, 1998), exemplifying how environmentalism has developed into a more dispersed and diffuse movement (Jamison, 2001), suggested to be increasingly defined by everyday actions (Loftus, 2012).

\section{Conclusion}


In this article we have studied organisational politics by analysing everyday environmental actions amongst employees of the energy utility, Ordalia. Using qualitative research methods, including participant observations, shadowing, interviews and conversations, we have first positioned ourselves empirically within an organisation producing both electricity and pollution, and second, analysed the empirical material by merging Rancière's method of equality and notion of partaking with the social movement concept of prefiguration. Developing a conception of prefigurative partaking, we have theorised everyday environmental activism pursued by Ordalia employees at work. From our empirical material, we have categorised six characterising themes of prefigurative partaking, which cannot be pinpointed either as a politicisation from the 'inside' or from the 'outside' (cf. Clegg et al., 2018): aspirational, individual, professional, critical, loyal and communal.

Our analysis shows how employees, when faced with what Rancière calls 'dissociation', i.e. a disruption of the sensible world they inhabit, engage in positive action, aiming to create a better world in the here and now. This kind of activism cuts across established organisational hierarchies, engendering a radically horizontal form of politics. Our concept of prefigurative partaking thus facilitates the study of activism in a turbulent political landscape, where actions become more dispersed and boundaryless, discarding traditional understandings of politics and activism inside or outside of organisations (Rancière, 2016, p.113).

This approach offers three main contributions. First, employees' environmental activism should be understood as being incremental based on a 'pro' agenda that alters rather than counters. Second, this form of activism can be conceived as horizontal, from which an uncharted alternative form of organising unfolds. And third, it is based on a collective movement (rather than on an organised collective of actors) that is boundaryless insofar as the employees hold an exclusive bridging knowledge position that connects the 'inside' with the 'outside', transgressing traditional forms of organised politics. Affirming Rancière's method of equality and analytically focusing on 'prefigurative partaking', this furthers the existing problematisation in organisation studies of the 'inside' and 'outside' perspectives in the merger with literatures on activism (Soule, 2012), giving a deeper theoretical grounding for explorations of a broader array of activisms that permeate organisations. Hence, our findings show how activism at work can transcend institutional boundaries (cf. McAdam \& Scott, 2005), or what Huault et al. (2014) call the 'micro' and 'macro' of emancipation.

With Rancière's political philosophy, not only can we affirm a wider array of spheres that can be seen as properly political, but also a wider array of actions (Huault et al., 2014). Instead of focusing on 'negative conceptions of protest' or 'political and intellectual elites who "see the truth"' (Ibid., p. 42), we have applied an outward-looking process (cf. Maeckelbergh, 2011), enabling us to affirm 'positive assertions' of environmental engagement among employees who enact dissensus instead of seeking consensus (Huault et al., 2014), often by deploying an everyday environmentalism (Loftus, 2012) that is more 'pro' a specific cause rather than 'contra' a specific actor. In comparison to anti-identitarian (Eleftheriadis, 2015), anticapitalistic (Dixon, 2014) and anti-hierarchical (Kaufman, 2016) activism, pro-environmental activism may thus be easier to pursue at work. It aligns more easily with certain corporate, including profit-seeking, goals (Meyerson \& Scully, 1995), and is less threatening to business in comparison to other types of struggle (cf. Briscoe \& Gupta, 2016).

Consequently, we argue that prefigurative partaking leads to incremental changes in the here and now (Maeckelbergh, 2016). Such an outlook of organisational politics is, we believe, what Cooper (1986) had in mind when he conceptualised organisation as 'disorganization'. It 
complements what we know about infra-politics within organisations (Scott, 2005; Böhm et al., 2008) in that it spans presumed organisational boundaries, allowing it to 'reflect the larger trends and politics of society' (Zald \& Berger, 1978, p.825). Hence, our analysis has highlighted that employees can prefiguratively partake and thereby infuse transformation within many topics, including environmental problems caused by their employer. Despite earlier studies' incessant illustrations of how political engagement is utilized by capitalistic forces (e.g see Cederström \& Marinetto, 2013; Nyberg et al., 2013), we have emphasized the ways in which employees' political engagement can lead to transformations (Parker \& Parker, 2017).

Our main argument is thus that activism should neither be empirically policed, and kept at a morally safe distance 'externally' to corporations, nor should it be theoretically policed, confined to explanations seeking to pin activism down and confine it to causal categories or a 'true' activist identity (Bobel, 2007). Such an open and dispersed view of activism is perhaps particularly of relevance today, as digital communication is reshaping social connections, including politics. Yet, this dispersion also means that other, already well-understood, organisational processes should not be excluded from our view and analysis. For example, organisational control mechanisms via CSR (Costas \& Kärreman, 2013), sustainability (Wright et al., 2012) and market mechanisms (Adler et al., 2008), are equally valid frames of evaluation and scrutiny. Yet, to speak according to Rancière (2010), activism cannot be confined - neither inside nor outside corporate organisations. Activist politics is a dispersed phenomenon and should be studied, and thereby better understood, as such.

\section{References}

Ackroyd, S., \& Thompson, P. (1999). Organizational Misbehaviour. London: Sage.

Adler, S. P., Kwon, S.W., \& Heckscher, C. (2008). Professional Work: The Emergence of Collaborative Community. Organization Science, 19(2), 359-376.

Allen, S., Marshall, J., \& Easterby-Smith, M. (2015). Living With Contradictions: The Dynamics of Senior Managers' Identity Tensions in Relation to Sustainability. Organization \& Environment, 28(3), 328-348.

Alvesson, M., \& Robertson, M. (2015). Money Matters: Teflonic Identity Manoeuvring in the Investment Banking Sector. Organization Studies, 37(1), 7-34.

Alvesson, M., \& Willmott, H. (1992). On the idea of emancipation in management and organization studies. Academy of Management Review, 17(3), 432-464.

Banerjee, B. S. (2002). Corporate environmentalism: the construct and its measurement. Journal of Business Research, 55(3), 177-191.

Banerjee, S. B. (2003). Who sustains whose development? Sustainable development and the reinvention of nature. Organization Studies, 24(1), 143-180.

Bansal, P., Gao, J., \& Qureshi, I. (2014). The Extensiveness of Corporate Social and Environmental Commitment across Firms over Time. Organization Studies, 35(7), 949966.

Bertels, S., Hoffman, J. A., \& DeJordy, R. (2014). The Varied Work of Challenger Movements: Identifying Challenger Roles in the US Environmental Movement. Organization Studies, 35(8), 1171-1210.

Billig, M. (1995). Rhetorical Psychology, Ideological Thinking and Imagining Nationhood. In H. Johnston \& B. Klandermans (Eds.), Social movements and culture. Minneapolis: University of Minnesota Press.

Bobel. (2007). 'I'm not an activist, though I've done a lot of it': Doing Activism, Being Activist and the 'Perfect Standard' in a Contemporary Movement. Social Movement Studies, 6(2), 147-159. 
Boggs, C. (1977). Marxism, prefigurative communism, and the problem of workers' control. Radical America, 11(6), 99-122.

Braverman, H. (1974). Labor and monopoly capital: The Degradation of Work in the Twentieth Century. New York: Monthly review press.

Brewis, J., Tyler, M., \& Mills, A. (2014). Sexuality and organizational analysis-30 years on: Editorial introduction. Organization, 21(3), 305-311.

Briscoe, F., \& Gupta, A. (2016). Social Activism In and Around Organizations. Academy of Management Annals 16, 10(1), 671-727.

Burawoy, M. (1979). Manufacturing consent: Changes in the labor process under monopoly capitalism: University of Chicago Press.

Böhm, S., Dinerstein, A. C., \& Spicer, A. (2010). (Im)possibilities of Autonomy: Social Movements in and beyond Capital, the State and Development. Social Movement Studies, 9(1), 17-32.

Böhm, S., Spicer, A., \& Fleming, P. (2008). Infra-political dimensions of resistance to international business: A Neo-Gramscian approach. Scandinavian Journal of Management, 24(3), 169-182.

Cederström, C., \& Marinetto, M. (2013). Corporate social responsibility á la the liberal communist. Organization, 20(3), 416-432.

Chatterton, P., \& Pickerill, J. (2010). Everyday activism and transitions towards postcapitalist worlds. Transactions of the Institute of British Geographers, 35(4), 475490.

Christensen, L. T., Morsing, M., \& Thyssen, O. (2013). CSR as aspirational talk. Organization, 20(3), 372-393.

Clegg, S., Geppert, M., \& Hollinshead, G. (2018, in press). Politicization and political contests in and around contemporary multinational corporations: An introduction. Human Relations.

Collinson, D. L. (2002). Managing humour. Journal of Management Studies, 39(3), 269-288.

Cooper, R. (1986). Organization/disorganization. Social Science Information, 25(2), 299-335.

Costas, J., \& Kärreman, D. (2013). Conscience as control - managing employees through CSR. Organization, 20(3), 394-415.

Courpasson, D., Dany, F., \& Clegg, S. (2012). Resisters at Work: Generating Productive Resistance in the Workplace. Organization Science, 23(3), 801-819.

Coyne, T. I. (1997). Sampling in qualitative research. Purposeful and theoretical sampling; merging or clear boundaries? Journal of Advanced Nursing, 26, 623-630.

Creed, W. E. D., \& Scully, A. M. (2000). Songs of Ourselves: Employees' Deployment of Social Identity in Workplace Encounters. Journal of Management Inquiry, 9(4), 391412.

Crotty, J. (2006). Reshaping the hourglass? The environmental movement and civil society development in the Russian Federation. Organization Studies, 27(9), 1319-1338.

Czarniawska, B. (1997). Narrating the Organization: Dramas of Institutional Identity. Chicago/London: The University of Chicago Press.

Dahan, M. N., Doh, P. J., Oetzel, J., \& Yaziji, M. (2010). Corporate-NGO collaboration: cocreating new business models for developing markets. Long Range Planning, 43(2), 326-342.

Daskalaki, M., \& Kokkinidis, G. (2017). Organizing Solidarity Initiatives: A Socio-spatial Conceptualization of Resistance. Organization Studies, 38(9), 1303-1325.

Dauvergne, P. (2016). Environmentalism of the rich. Cambridge, MA: Massachusetts Institute of Technology.

Davis, F. G., McAdam, D., Scott, W. R., \& Mayer, N. Z. (Eds.). (2005). Social Movements and Organization Theory. New York: Cambridge Uiversity Press. 
de Bakker, G. A., Frank, den Hond, F., King, B., \& Weber, K. (2013). Social Movements, Civil Society and Corporations: Taking Stock and Looking Ahead. Organization Studies, 34(5-6), 573-593.

Delmas, A. M., \& Toffel, W. M. (2011). Institutional Pressures and Organizational Characteristics: Implications for Environmental Strategy, in P. Bansal \& J. A. Hoffman (Eds.), The Oxford Handbook of Business and the Natural Environment. Oxford: Oxford University Press.

den Hond, F., \& de Bakker, G. A. F. (2007). Ideologically motivated activism: how activist groups influence corporate social change activities. Academy of Management Review, 32(3), 901-924.

Dixon, C. A. (2014). Another Politics - Talking Across Today's Transformative Movements. Oakland: University of California Press

Doherty, B., Plows, A., \& Wall, D. (2003). The preferred way of doing things': the British direct action movement. Parliamentary Affairs, 56(4), 669-686.

Ekman, S. (2014). Is the high-involvement worker precarious or opportunistic? Hierarchical ambiguities in late capitalism. Organization, 21, 141-158.

Eleftheriadis, K. (2015). Organizational Practices and Prefigurative Spaces in European Queer Festivals. Social Movement Studies, 14(6), 651-667.

Epstein, B. (1991). Political protest and cultural revolution: Nonviolent direct action in the 1970s and 1980s: University of California Press.

Esterhammer, A., \& Dick, A. J. (2009). Spheres of Action: Speech and Performance in Romantic Culture. Toronto and London: University of Toronto Press.

Farias, C. (2017). That's What Friends Are For: Hospitality and affective bonds fostering collective empowerment in an intentional community. Organization Studies, 38(5), $577-$ 595.

Fereday, J., \& Muir-Cochrane, E. (2006). Demonstrating Rigor Using Thematic Analysis: A Hybrid Approach of Inductive and Deductive Coding and Theme Development. International Journal of Qualitative Methods, 5(1), 80-92.

Fleming, P., \& Spicer, A. (2003). Working at a Cynical Distance: Implications for Power, Subjectivity and Resistance. Organisation, 6(1), 157-179.

Girschik, V. (2018, in press). Shared Responsibility for Societal Problems: The Role of Internal Activists in Reframing Corporate Responsibility. Business \& Society.

Goworek, H., Land, C., Burt, G., Zundel, M., Saren, M., Parker, M., \& Lambe, B. (2018). Scaling Sustainability: Regulation and Resilience in Managerial Responses to Climate Change. British Journal of Management, 29(2), 209-219.

Guénoun, S., Kavanagh, H. J., \& Lapidus, R. (2000). Jacques Rancière: Literature, Politics, Aesthetics: Approaches to Democratic Disagreement. SubStance, 29(92), 3-24.

Haug, C. (2013). Organizing Spaces: Meeting Arenas as a Social Movement Infrastructure between Organization, Network, and Institution. Organization Studies, 34(5-6), 705732 .

Hemingway, A. C., \& Maclagan, W. P. (2004). Managers' personal values as drivers of corporate social responsibility. Journal of Business Ethics, 50(1), 33-44.

Horton, D. (2006). Environmentalism and the Bicycle. Environmental Politics, 15(1), 41-58.

Huault, I., Perret, V., \& Spicer, A. (2014). Beyond macro-and micro-emancipation: Rethinking emancipation in organization studies. Organization, 21(1), 22-49.

Huber, G., \& Brown, A. D. (2017). Identity, work, humour and disciplinary power. Organization Studies, 38(8), 1107-1126.

Hysing, E., \& Olsson, J. (2018). Green Inside Activism for Sustainable Development: Political Agency and Institutional Change. Cham: Springer. 
Jacobsson, K., \& Sörbom, A. (2015). After a cycle of contention: Post-Gothenburg strategies of left-libertarian activists in Sweden. Social Movement Studies, 14(6), 713-732.

Jaffe, S. (2016). Necessary Trouble: Americans in Revolt. New York: Nation Books.

Jamison, A. (2001). The Making of Green Knowledge - Environmental Politics and Cultural Transformation. Cambridge: Cambridge University Press.

Karfakis, N., \& Kokkinidis, G. (2011). Rethinking cynicism: Parrhesiastic practices in contemporary workplaces. Culture and Organization, 17(4), 329-345.

Kaufman, C. (2016). Ideas for Action: Relevant Theory for Radical Change (2 ed.). Oakland: PM Press.

King, D., \& Land, C. (2018, in press). The democratic rejection of democracy: Performative failure and the limits of critical performativity in an organizational change project.

Human Relations.

Kokkinidis, G. (2015). Spaces of possibilities: workers' self-management in Greece. Organization, 22(6), 847-871.

Leach, K. D. (2013). Prefigurative Politics. In A. D. Snow, D. della Porta, B. Klandermans, \& D. McAdam (Eds.), The Wiley-Blackwell Encyclopedia of Social and Political Movements (pp. 1004-1005): Blackwell Publishing.

Loftus, A. (2012). Everyday Environmentalism: Creating an Urban Political Ecology. Minneapolis/London: University of Minnesota Press.

Luchies, T. (2015). Towards an insurrectionary power/knowledge: Movement-relevance, antioppression, prefiguration. Social Movement Studies, 14(5), 523-538.

MacKay, B., \& Munro, I. (2012). Information warfare and new organizational landscapes: An in quity into the ExxonMobil - Greenpeace dispute over climate change. Organization Studies, 33(11), 1507-1536.

Maeckelbergh, M. (2011). Doing is Believing: Prefiguration as Strategic Practice in the Alterglobalization Movement. Social Movement Studies, 10(1), 1-20.

Maeckelbergh, M. (2016). The prefigurative turn: The time and place of social movement practice. In A. C. Dinerstein (Ed.), Social sciences for an other politics. Women theorizing without parachute (pp. 121-134). Basingstoke: Palgrave-MacMillan.

Marens, R. (2013). What comes around: the early 20th century American roots of legitimating corporate social responsibility. Organization, 20(3), 454-476.

Maxey, I. (1999). Beyond boundaries?Activism, academia, reflexivity and research. Area, 31(3), 199-208.

McAdam, D., \& Scott, W. R. (2005). Organizations and movements. In F. G. Davis, D. McAdam, W. R. Scott, \& N. Z. Mayer (Eds.), Social Movements and Organization Theory. New York: Cambridge Uiversity Press.

Melucci, A. (1995). The process of collective identity. In H. Johnston \& B. Klandermans (Eds.), Social movements and culture 4 (pp. 41-63). Minneapolis: The University of Minnesota Press.

Mercea, D. (2016). Civic Participation in Contentious Politics - The Digital Foreshadowing of Protest London: Palgrave Mcmillan.

Meyer, S. D., \& Tarrow, G. S. (Eds.). (1998). The Social Movement Society: Contentious Politics for a New Century. Oxford: Rowman \& Littlefield Publishers.

Meyerson, E. D., \& Scully, A. M. (1995). Tempered Radicalism and the Politics of Ambivalence and Change. Organization Science, 6(5), 585-600.

Moore, R., \& Roberts, M. (2009). Do-it-yourself mobilization: Punk and social movements. Mobilization: An International Quarterly, 14(3), 273-291.

Morse, J. (1995). The significance of saturation. Qualitative Health Research, 5(2), 147-149.

Mumby, K. D., Thomas, R., Martí, I., \& Seidl, D. (2017). Resistance Redux. Organization Studies, 38(9), 1157-1183. 
Nyberg, D., Spicer, A., \& Wright, C. (2013). Incorporating citizens: corporate political engagement with climate change in Australia. Organization, 20(3), 433-453.

O'Reilly, M., \& Parker, N. (2012). 'Unsatisfactory Saturation': a critical exploration of the notion of saturated sample sizes in qualitative research. Qualitative Research, 13(2), 190-197.

Pacheco, D. F., York, J. G., \& Hargrave, T. J. (2014). The coevolution of industries, social movements, and institutions: Wind power in the United States. Organization Science, 25(6), 1609-1632.

Parker, M., Cheney, G., Fournier, V., \& Land, C. (Eds.). (2014). The Routledge companion to alternative organization. London: Routledge.

Parker, S., \& Parker, M. (2017). Antagonism, accommodation and agonism in Critical Management Studies: Alternative organizations as allies. Human Relations, 70(11), 1366-1387.

Pellow, D. N. (2000). Environmental inequality formation: Toward a theory of environmental injustice. American Behavioral Scientist, 43(4), 581-601.

Perrault, E., \& Clark, C. (2016). Environmental Shareholder Activism: Considering Status and Reputation in Firm Responsiveness. Organization and Environment, 29(2), 194211.

Pondy, L. R. (1967). Organizational conflict: Concepts and models. Administrative Science Quarterly, 12(2), 296-320.

Rancière, J. (1999). Disagreement: politics and philosphy. Minneapolis: The university of Minnesota press.

Rancière, J. (2003). The Philosopher and His Poor: Duke University Press.

Rancière, J. (2010). Dissensus - on politics and aesthetics. London: Continuum.

Rancière, J. (2014). The emancipated spectator. London: Verso Books.

Rancière, J. (2015). Dissensus - on politics and aesthetics. London/New York: Bloomsbury academic.

Rancière, J. (2016). The method of equality. Cambridge: Polity Press.

Reedy, P., King, D., \& Coupland, C. (2016). Organizing for Individuation: Alternative Organizing, Politics and New Identities. Organization Studies, 37(11), 1553-1573.

Reinecke, J. (2018 (In press)). Social Movements and Prefigurative Organizing: Confronting entrenched inequalities in Occupy London. Organization Studies, 1-23.

Reitan, R. (2010). Coordinated Power in Contemporary Leftist Activism. In T. Olesen (Ed.), (pp. 67-88), Power and Global Activism. London: Routledge.

Rhodes, C., Wright, C., \& Pullen, A. (2018). Changing the World? The Politics of Activism and Impact in the Neoliberal University. Organization, 25(1), 139-147

Routledge, P. (2012). Sensuous solidarities: emotion, politics and performance in the Clandestine Insurgent Rebel Clown Army. Antipode, 44(2), 428-452.

Schmidt, S. M., \& Kochan, T. A. (1972). Conflict: Toward conceptual clarity. Administrative Science Quarterly, 17(3), 359-370.

Scoones, I., Leach, M., \& Newell, P. (Eds.). (2015). The politics of green transformations. New York: Routledge, Earthscan.

Scott, C. J. (2005). The infrapolitics of subordinate groups. In L. Amoore (Ed.), The Global Resistance Reader (pp. 65-73). Oxford: Routledge.

Scully, M., \& Segal, A. (2002). Passion with an Umbrella: Grassroots Activism in the Workplace. Social Structure and Organizations Revisited, 19, 125-168.

Shrivastava, P. (1994). Castrated environment: Greening organizational studies. Organization Studies, 15(5), 705-726.

Smith, J., Goodhart, M., Manning, P., \& Markoff, J. (Eds.). (2017). Social Movements and World-System Transformation. London and New York: Routledge. 
Sonenshein, S. (2016). How Corporations Overcome Issue Illegitimacy and Issue Equivocality to Address Social Welfare: The Role of the Social Change Agent. Academy of Management Review, 41(2), 349-366.

Soule, S. A. (2012). Social Movements and Markets, Industries, and Firms. Organization Studies, 33(12), $1715-1733$.

Spicer, A., Alvesson, M., \& Kärreman, D. (2009). Critical performativity: The unfinished business of critical management studies. Human Relations, 62, 537-560.

Spicer, A., \& Böhm, S. (2007). Moving Management: Theorizing Struggles against the Hegemony of Management. Organization Studies, 28(11), 1667-1698.

Sutherland, N., Land, C., \& Böhm, S. (2014). Anti-leaders(hip) in Social Movement Organizations: The case of autonomous grassroots groups. Organization, 21(6), 759781.

Sørensen, J. M. (2016). Humour in Political Activism Creative Nonviolent Resistance. London: Palgrave Macmillan.

Tarrow, S. G. (2011). Power in movement: Social movements and contentious politics. New York: Cambridge University Press.

Thompson, P., \& Ackroyd, S. (1995). All quiet on the workplace front? A critique of recent trends in British industrial sociology. Sociology, 29(4), 615-633.

Uusi-Rauva, C., \& Heikkurinen, P. (2013). Overcoming Barriers to Successful Environmental Advocacy Campaigns in the Organizational Context, Environmental Communication, 7(4), 475-492.

Waldron, T., Navis, C., \& Fisher, G. (2013). Explaining differences in firms' responses to activism. Academy of Management Review, 38(3), 397-417.

Wapner, P. K. (1996). Environmental activism and world civic politics: Suny Press.

Wickert, C., \& Schaefer, M. S. (2015). Towards a progressive understanding of performativity in critical management studies. Human Relations, 68(1), 107-130.

Wickert, C., \& De Bakker, F. (2018). Pitching for Social Change: Toward a Relational Approach to Selling and Buying Social Issues. Academy of Management Discoveries, 4(1), 50-73.

Wittneben, B. F. B., Okereke, C., Banerjee, B. S., \& Levy, L. D. (2012). Climate change and the emergence of new organizational landscapes. Organization Studies, 33(11), 14311450.

Wright, C., Nyberg, D., De Cock, C., \& Whiteman, G. (2011). Call for papers - special issue for Organization. Future Imaginings: Organizing in response to climate change. Organization.

Wright, C., Nyberg, D., \& Grant, D. (2012). "Hippies on the third floor": Climate Change, Narrative Identity and the Micro-Politics of Corporate Environmentalism. Organization Studies, 33, 1451-1475.

Yates, L. (2015). Rethinking Prefiguration: Alternatives, Micropolitics and Goals in Social Movements. Social Movement Studies, 14(1), 1-21.

Yaziji, M., \& Doh, P. J. (2013). The Role of Ideological Radicalism and Resource Homogeneity in Social Movement Organization Campaigns against Corporations. Organization Studies, 34(5-6), 755-780.

Zald, N. M., \& Berger, A. M. (1978). Social Movements in Organizations: Coup d'Etat, Insurgency, and Mass Movements. American Journal of Sociology, 83(4), 823-861.

Zietsma, C., \& Winn, I. M. (2008). Building Chains and Directing Flows: Strategies and Tactics of Mutual Influence in Stakeholder Conflicts. Business \& Society, 47(1), 68101. 
Table I. Summary of empirical material.

\begin{tabular}{ll}
\hline Empirical material & Description \\
\hline Participant observation (I day) & $\begin{array}{l}\text { Department meeting and site visit at Swedish wind power park, } \\
\text { Western Sweden } \\
\text { Information to general public about wind development, Southern } \\
\text { Sweden }\end{array}$ \\
Observations (I day) & Project manager, female, headquarters, Sweden \\
Shadowing (I day) & Director of Ordalia Wind, female, headquarters, Sweden \\
Shadowing (I day) & Project manager, male, headquarters, Sweden \\
Shadowing (I day) & Environmental manager, female, Western Swedish office \\
Shadowing (2 days) & Ordalia headquarters, UK \\
Participant observations (20 days) & Ordalia office, Northeast UK \\
Participant observations (3 days) & Ordalia office, Southwest UK \\
Participant observations (4 days) & I6 recorded and transcribed \\
Interviews Sweden & I7 recorded and transcribed \\
Interviews UK & Director of environment, Environmental manager (Sweden), HR \\
Continuous feedback meetings & manager Ordalia Continental, Country manager (UK). \\
\end{tabular}


Table 2. Summary of anonymous interviewees.

\begin{tabular}{|c|c|c|}
\hline Swedish interviewees & Age & Title \\
\hline Anna & $25-30$ & Project coordinator \\
\hline Bodil & $35-40$ & Environmental assessment manager \\
\hline Cecilia & $35-40$ & Project manager \\
\hline Desiré & $45-50$ & Juridical expert \\
\hline Erik & $35-40$ & Project manager \\
\hline Fredrik & $50-60$ & Environmental assessment manager \\
\hline Gunilla & $25-30$ & HR business partner onshore wind \\
\hline Hedvig & $40-45$ & Director of onshore engineering \\
\hline Ivan & $35-40$ & Onshore wind business analyst \\
\hline Julia & $35-40$ & Project manager \\
\hline Karl & $40-45$ & Onshore wind business analyst \\
\hline Lennart & $35-40$ & Project manager \\
\hline Miriam & $45-50$ & Director wind power development \\
\hline Nils & $35-40$ & External environmental assessment consultant \\
\hline Olivia & $35-40$ & Employer brand officer \\
\hline $\mathrm{Pia}$ & $40-45$ & Director of environment \\
\hline Rosmarie & $40-45$ & Environmental manager \\
\hline Simon & $45-50$ & Senior Vice President of Strategic Development \\
\hline \multicolumn{3}{|l|}{ UK interviewees } \\
\hline Adam & $45-55$ & Senior commercial manager \\
\hline Beatrice & $30-35$ & Valuation modeler \\
\hline Clarke & $35-45$ & Senior project manager wind development \\
\hline David & $30-35$ & Operations and maintenance manager \\
\hline Eva & $35-40$ & Onshore sites manager \\
\hline Felicia & $35-40$ & Project administrator \\
\hline George & $35-45$ & Project manager \\
\hline Helen & $35-45$ & Environmental officer \\
\hline lan & $45-50$ & Interface manager \\
\hline Jane & $50-60$ & Director of law \\
\hline Kirsten & $30-35$ & Environmental and contents manager \\
\hline Liz & $35-40$ & Project administrator \\
\hline Martin & $30-35$ & Project administrator \\
\hline Natalie & $35-40$ & Operations readiness officer \\
\hline Olga & $35-40$ & Ocean analyst \\
\hline Peter & $35-40$ & Valuation modeler \\
\hline Richard & $55-60$ & Quality manager \\
\hline Stephen & $30-35$ & HR manager continental \\
\hline Thomas & $45-50$ & Country manager UK, Director Ordalia offshore wind \\
\hline
\end{tabular}


Figure 1. Structure for analysing prefigurative partaking

Data examples

First order concepts Characterizing themes Aggregate dimension

Calling for a 'renewable people'

Creating a relation to the environment

Being part of the solution

Overhaul how things are done

Create a better world

Walking up the stairs instead of taking the elevator

Turning off the computer screen

Setting up recycle bins

Sorting other's lunch rubbish

Using a ceramic cup instead of a

paper cup

Influencing supply chains
Persuading communities about new
wind development projects
Recruiting people with an interest in
environmental issues
Arranging horse riding among wind
turbines
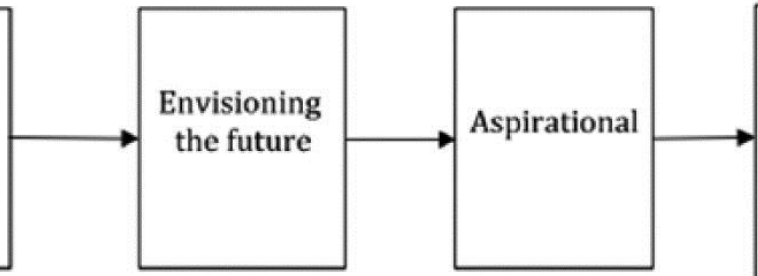

Complaining about the lack of coherence between employee wishes and corporate environmental management and strategy

Proposing close down rather than sell out of coal fired power plants

Expressing faith and belief in the
organization whilst criticizing it
Pointing out problems and
naturalizing them
Bridging the gap between the internal
environmental engagement and the
external critique

Showing photos of lignite operations

Engaging on the Intranet

Clean beaches

Sharing nostalgic flashbacks

Volunteering as interviewee

Writing letters to members of

parliament

Signing petitions
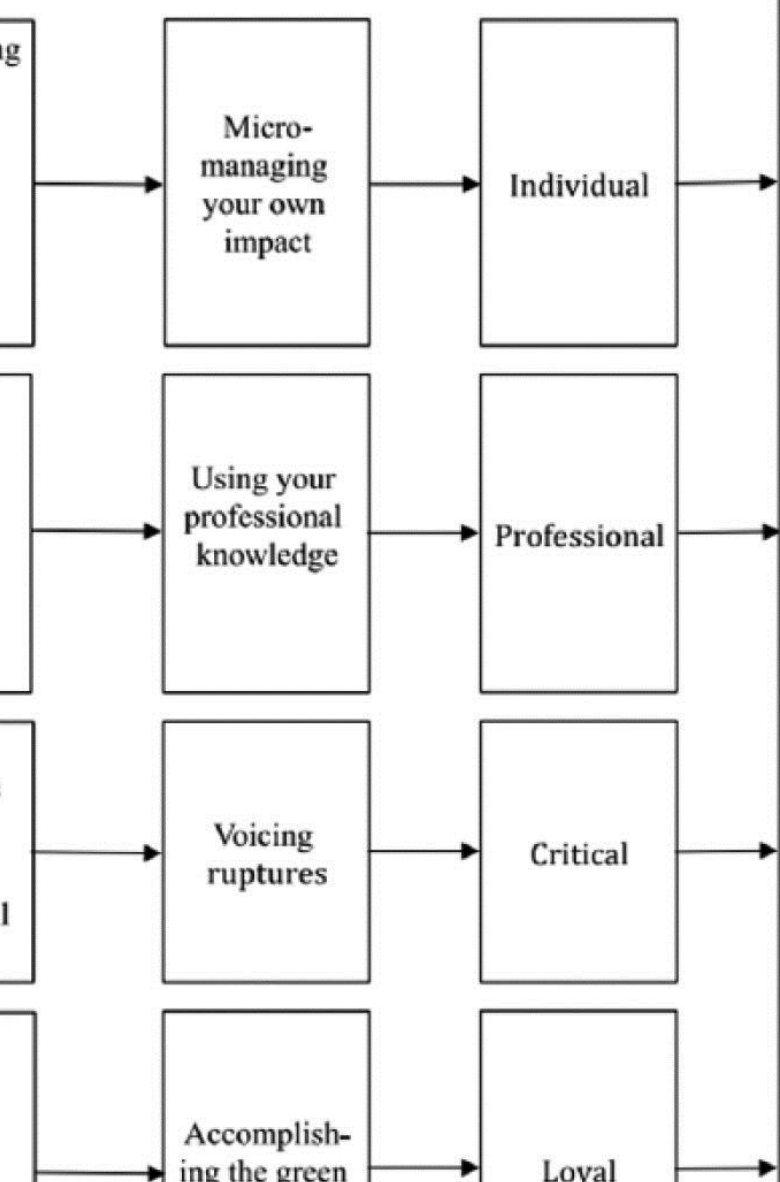

Prefigurative
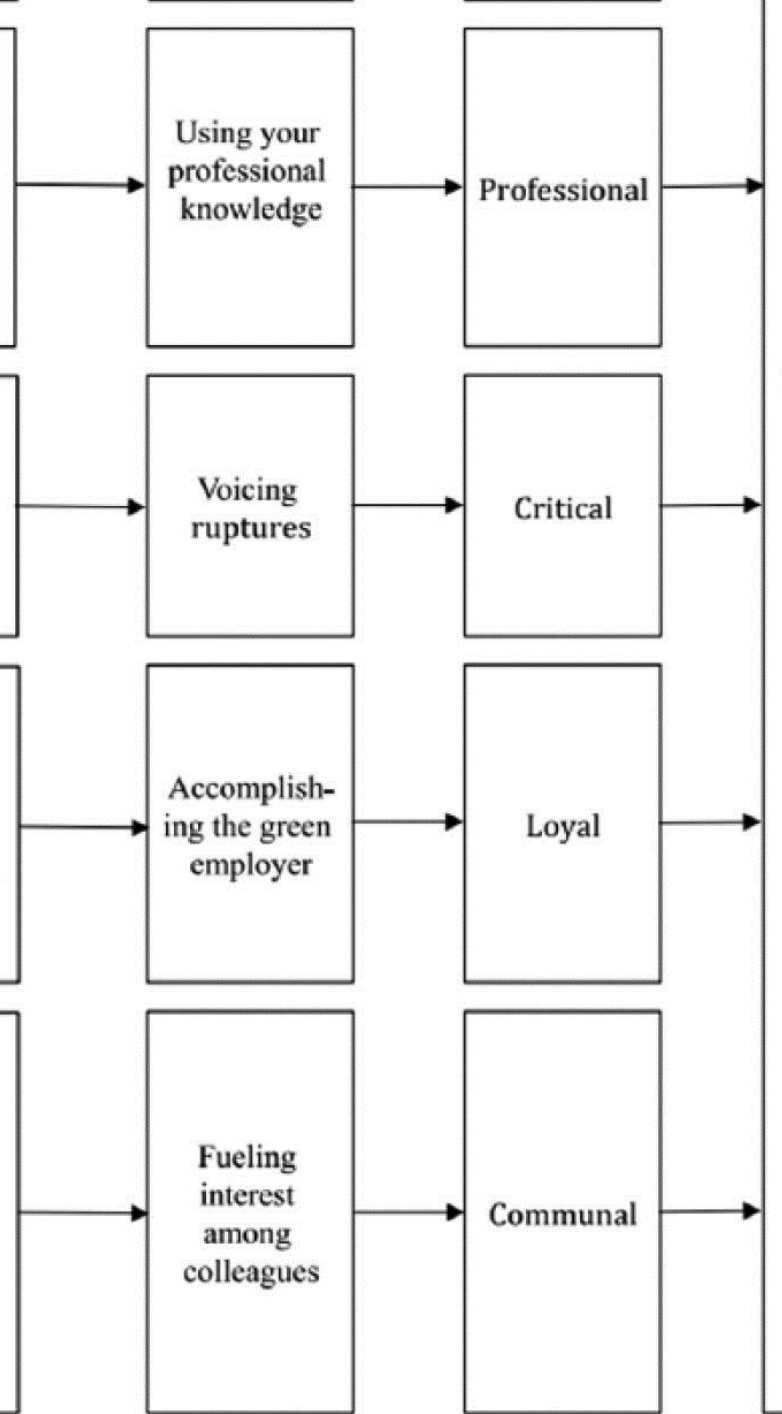
partaking

Figure 2. Erik showing a recycling bin at the Swedish headquarters. 


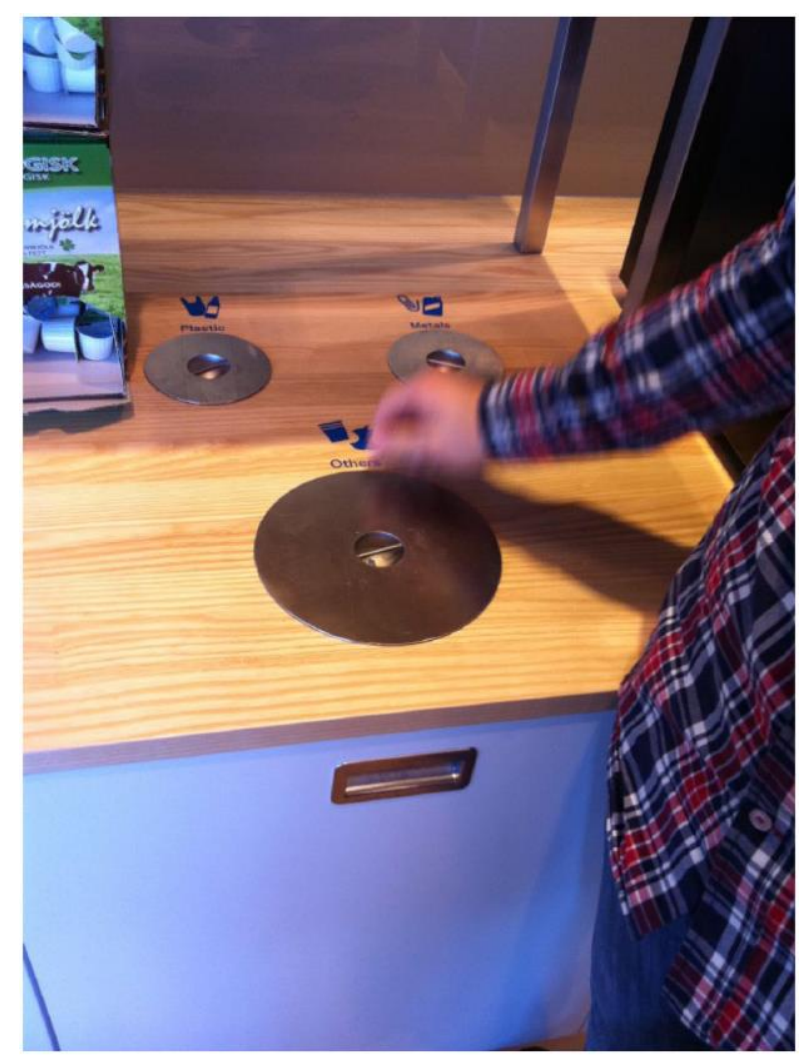


Figure 3. Northern UK office entrance with wallpaper showing offshore wind turbines.

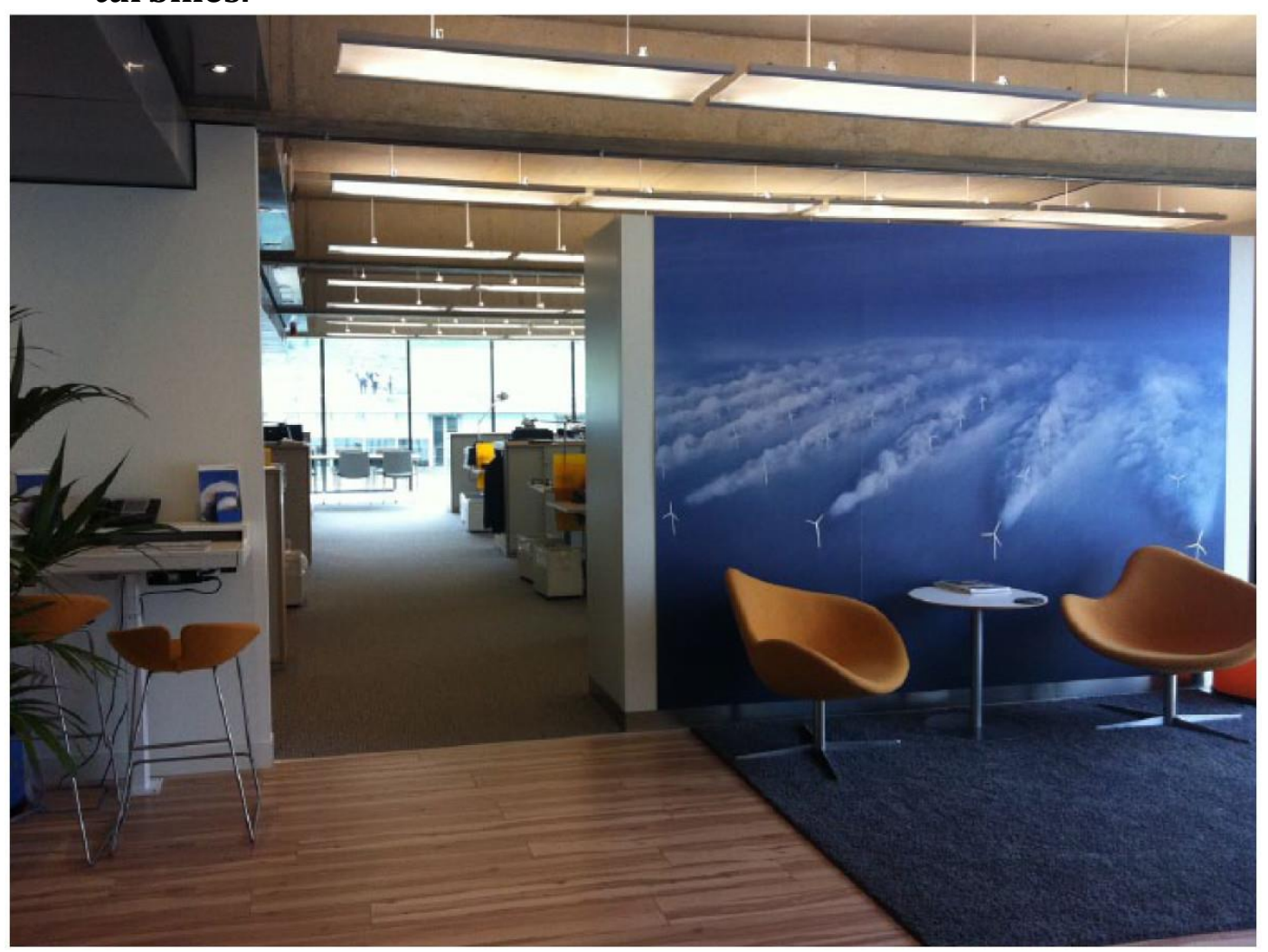


Figure 4. Comic strip at a desk in an open office at headquarters, Stockholm.

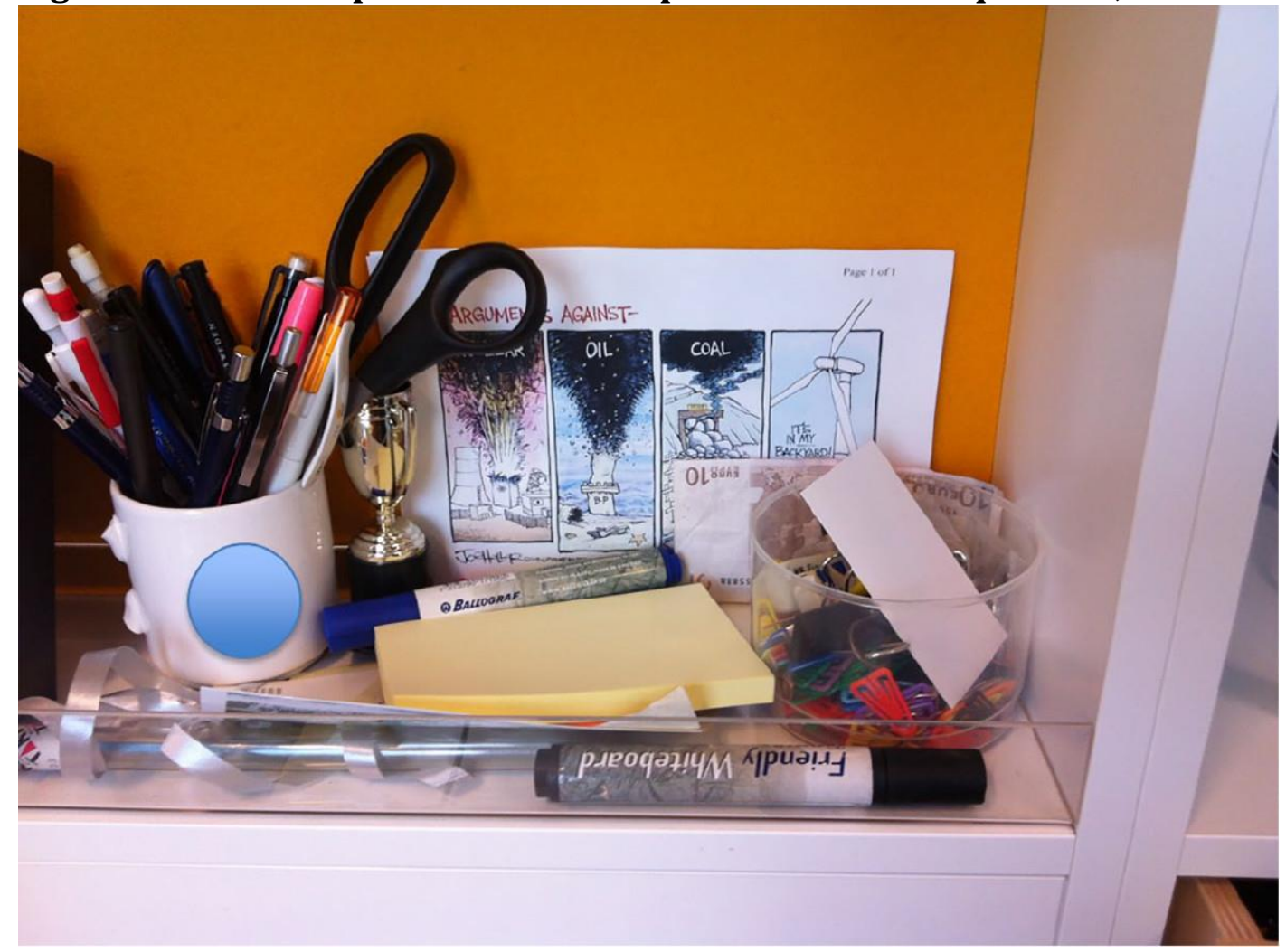

